\title{
FATHOM
}

\section{"Unholy Exclamations"}

Scripture as Fetish in Far from the Madding Crowd

"Unholy exclamations" : le fétiche des Écritures dans Far from the Madding crowd

\section{Jacqueline Dillion}

\section{OpenEdition}

\section{Journals}

\section{Electronic version}

URL: http://journals.openedition.org/fathom/214

DOI: $10.4000 /$ fathom. 214

ISSN: 2270-6798

Publisher

Association française sur les études sur Thomas Hardy

\section{Electronic reference}

Jacqueline Dillion, « "Unholy Exclamations" », FATHOM [Online], 1 | 2013, Online since 10 July 2013,

connection on 26 April 2019. URL : http://journals.openedition.org/fathom/214 ; DOI : 10.4000/

fathom. 214

This text was automatically generated on 26 April 2019. 


\title{
"Unholy Exclamations"
}

\author{
Scripture as Fetish in Far from the Madding Crowd \\ "Unholy exclamations" : le fétiche des Écritures dans Far from the Madding \\ Crowd
}

Jacqueline Dillion

Thomas Hardy's early novel Far from the Madding Crowd (1874) is often remembered for its pastoral scenes and lively rustic characters. For these characters daily speech is peppered with remnants of biblical scripture and biblical ideas, yet, this same speech is imbued with folk beliefs that are more fetishistic than doctrinal. Throughout the novel these fetishized scriptural words function in a variety of ways: to "magically" open doors, to threaten or curse - even to determine the spiritual state of these characters' souls. Hardy's characters consistently see relationships between the spoken or written word and the state of their personal salvation (or lack thereof), and yet their assertions seem continually problematic, for they inextricably infuse strong folk interpretations into biblical scripture, Anglican liturgy, and Christian doctrine, making the result complex, confused, and paradoxical. Hardy frames their confusion against the ongoing struggle between the Anglican and Nonconformist churches (or High Church versus High Chapel as described in the novel), leaving these characters to rely on a more "folk" approach of fetishizing words to affirm their spiritual state. While the result often appears humorous, the comedy belies the palpable angst and tension informing this speech.

2 Over the course of his writing career Hardy was strongly influenced by the works of Auguste Comte who viewed "fetishism" as that earliest stage of thought in which, according to Peter Logan "object and god, signifier and signified, are one and the same [... ] [R]ather than a representation of meaning, the fetish is meaning itself" (Logan 10). While the term "fétiche" had been first popularized by Charles de Brosses in 1757, Hardy was drawn to Comte's treatment of the idea, which he copied into his Literary Notebooks, recording (among others) the lines: "Fetichism - looks on all objects in nature as animate" and "Fetichism is the most spontaneous mode of philosophizing, \& useful even now, giving animation to language \&c -" (Hardy 1985, entries 754-7551). Though these notes would be compiled a few years after the publication of far From the Madding Crowd 
when he was reading (or possibly re-reading) Comte's Social Dynamics, it is likely that he had encountered Comte's notion before this time. Another more contemporary source of influence in the concept of fetishism is Edward Tylor's 1871 landmark study Primitive Culture. Though it is debatable whether Hardy had yet read Primitive Culture directly in the 1870s (Garrigan-Mattar 11), Tylor's ideas were rapidly gaining currency in the period in which Hardy was writing Far from the Madding Crowd. In Primitive Culture Tylor offered a definition of fetishism as being a "doctrine of spirits embodied in, or attached to, or conveying influence through, certain material objects" (Tylor II 132). While Tylor generally associates fetishism with non-Western cultures or even the "survivals" of more "primitive" Western cultures, such as Europeans formerly driving a "mediaeval devil into an old sow" (146), Tylor sees Western and non-Western cultures as evolving along the same track: "the theory of the soul is one principal part of a system of religious philosophy, which unites, in one unbroken line of mental connection, the savage fetishworshipper and the civilized Christian" (Tylor I 435). The implications of Tylor's theory were significant, and George Stocking regards Tylor's theory as one of the most important such statements in the late nineteenth century (Stocking 55). But while Tylor saw a linear "unbroken line of development", Hardy understands fetishism to be "always returning as both a psychological and a creative imperative that exists outside of Time, and outside the 'stages' of evolutionary development" (Garrigan-Mattar 16); thus fetishism is a living, evolving thing and a concept that may be applied to language as well as to material objects. Given Hardy's later recorded interest in fetishism and his incorporation of the concept of the fetish into The Return of the Native (1878), it is conceivable that he began to develop an awareness of the idea in the wake of Primitive Culture (1871) and that these ideas in their early stages find voice in Far from the Madding Crowd. But with Hardy, contemporary cultural theory is only a springboard for his own creative re-working in the world of his fiction. As Robert Schweik believes, contemporary ideas like Comte's and Tylor's are "embedded in a densely intricate web of imaginative connections and qualifications so complex that a consideration of them can hope only partly to illuminate the manifold ways they have influenced [Hardy's] writings" (Schweik 54).

3 While Far from the Madding Crowd lacks some of the more overt "pagan" practices such as waxen effigy burning found in The Return of the Native, the novel's use of fetishistic language inspired by the "letter" of biblical law and scripture is important. This dichotomy between the restrictive "letter" of biblical authority and the spiritual energy of the Hardyan folk mindset gives full reign to the possibilities of folk imagination in this work. Mary Rimmer, in her article on biblical language in Hardy calls the result "shiftiness" (Rimmer 20), and the reader is never quite sure where Hardy's characters stand spiritually, but perhaps, significantly, neither do they. And possibly, neither does Hardy, as he would later make substantial changes for the Wessex edition over what he submitted in manuscript form to Cornhill magazine. For the purposes of this paper, I will be citing examples from both the Wessex edition of Far from the Madding Crowd edited by Suzanne Falck-Yi (Hardy 2002) and the original manuscript edition edited by Rosemarie Morgan (Hardy 2000).

One of the first instances of fetishized words in the novel reads as a positive, fortuitous outcome of word-power: that of Joseph Poorgrass and the locked gate. Poorgrass is known in the parish for what he calls his "scripture manner" or his ability to apply biblical scripture, liturgy, or vaguely familiar religious doctrine to any situation, though most of 
these references are incorrectly applied and to humorous effect. He views a locked gate that will not open as having "the devil's hand in it", responding thus:

My heart died within me that time; but I kneeled down and said the Lord's Prayer, and then the Belief right through, and then the Ten Commandments, in earnest supplication. But no, the gate wouldn't open, and then I went on with Dearly Beloved Brethren, and thinks I, this makes four and 'tis all I know out of book, and if this don't do it nothing will, and I'm a lost man. Well, when I got to Saying After Me I rose from my knees and found the gate would open - yes neighbours, the gate opened the same as ever. (Hardy 2002, 62)

5 Poorgrass' behaviour is more fetishistic than orthodox, for he kneels, presumably before the devil, in a posture not unlike the oxen of Hardy's poem of the same name, who famously kneel in holy reverence at Christmas. Then Poorgrass recites a desperate combination of Christian prayer, old Testament law, and Anglican liturgy as a kind of countercharm against the devil's trickery. While the story may be read humorously, in Victorian Dorset children were taught to recite the Lord's Prayer backwards when passing by possible witches believed to be "in league with the devil," as Geoff and Fran Doel record in their study on Dorset folklore (Doel 113). In their work the source recalls being too afraid to properly remember this backwards recitation - echoing Poorgrass' fear that he will run out of scripture - fear that he will be "a lost man." For a rural farm labourer such as Poorgrass the danger alluded to cannot mean merely spending the night outdoors, but instead must mean to be on the losing side against the devil - quite frightening indeed. While Poorgrass himself sincerely tells the story in first person, his narrative follows a similar formula to the catalogued folkloric tradition "Devil disappears on hearing a hymn tune," which Peter Robson discusses in his dissertation on folklore in Hardy (Robson 87). So while the word-fetish here may alter from a hymn to a prayer or bit of liturgy, crucially, the effect is the same.

6 While Joseph Poorgrass' narrative has a "happy ending," there are other more ominous instances of fetishized words and their legacy. The character Cain Ball's first name is one such example, as a fellow labourer describes:

"Oh you see, mem, his pore mother, not being a Scripture-read woman, made a mistake at his christening, thinking 'twas Abel killed Cain, and called en Cain, meaning Abel all the time. The parson put it right, but 'twas too late, for the same could never be got rid of in the parish [...] however we soften it down as much as we can and call him Cainy. Ah, poor widow woman! She cried her heart out about it almost. She was brought up by a very heathen father and mother who never sent her to church or school, and it shows how the sins of the parents are visited upon the children, mem." (Hardy 2002, 82)

7 It is perhaps bizarre why anyone would want to name her son after the Bible's first murder victim, but indeed, it is considered a powerful ill omen that instead the boy is named after the first murderer. And as the speaker acknowledges the old Testament concept of "the sins of the parents" applying to Cain's grandparents' culpability for the mother's ignorance, the speaker also consciously or unconsciously applies this logic to Cain, who will suffer discrimination and ill-treatment from his elders later in the novel. The excerpt above is taken from the revised Wessex edition of 1912; Hardy originally wrote "and called en Cain, meaning Abel all the time. She didn't find it out till 'twas too late, and the chiel was handed back to his godmother" (Hardy 2000, 72, emphasis mine). That Hardy years later was still interested in this idea so as to revise the sentence from the original "godmother" to an ineffectual "village parson" shows that the power of the fetishized word, here, an unlucky biblical name, is stronger than the power of the church as the 
community sees it, and indicates Hardy's fascination with this ongoing struggle between church teaching and folk belief (Hardy 2000, introduction xxiii). Though the parson "put [s] it right" it is as if the folk community is controlled by the higher power of this dreaded name, and they are powerless to change it, no matter who suffers, and Cain will. It may be worth noting an unusual line shortly after about Cain's grandfather "inventing" an apple tree (Hardy 2002, 218), an anecdote that reinforces this connection between the biblical Cain, whose "grandfather" would be God, creator of the Tree of Life, which is historically represented as an apple tree.

8 The characters in Far from the Madding Crowd have a unique fixation on and complicated relationship with the word "damn." The first example of this usage in the novel actually occurs in the manuscript and serialized Cornhill versions, but Hardy later removed it in the Wessex edition for its implications. In the malthouse scene, Gabriel Oak hears Jacob Smallbury use the expression "dang it all" in conversation, and Oak meditates to himself: "whether the saving to a man's soul in the run of a twelvemonth by saying Dang instead of what it stood for made it worth while to use the word" (Hardy 2000, 51). It is a curious line, for Gabriel, who is considered less superstitious than his contemporaries, is actually calculating how many times he uses the word "damn" in a year, as if his natural instinct for calculating prices with agriculture sees a similar correlation between the degree to which his soul can be saved or not depending on the use of a particular word or its variant. While this musing would seem to provide insight into farmers and farm labourers' attitudes on swearing, Hardy removed this passage in the Wessex edition in a concerted effort to "ennoble Oak's character," a complicated revision that Rosemarie Morgan explains in Cancelled Words and in the manuscript edition of the novel (Morgan 78; Hardy 2000, 361 footnote 11).

9 This fixation with the word "damn" also appears, though more disturbingly, in another malthouse conversation where farm labourer Jan Coggan reflects back on Farmer Everdene's and Coggan's wife Charlotte's disapproval of the word - even when drinking:

"Not a single damn allowed: no, not a bare poor one, even at the most cheerful moment when all were blindest; though the good old word of sin thrown in here and there would have been a great relief to a merry soul."

"True" said the Maltster. "Nater requires her swearing at the regular times, or she's not herself; and unholy exclamations is a necessity of life."

"But Charlotte," continued Coggan, "- not a word of the sort would Charlotte allow, nor the smallest item of taking in vain... Ay, poor Charlotte - I wonder if she had the good fortune to get into Heaven when 'a died! But 'a was never much in luck's way, and perhaps 'a went downwards after all poor soul.” (Hardy 2002, 63)

Coggan thus speaks affectionately of the fetishized word "damn," and the maltster agrees that swearing by this word is so natural that nature requires this utterance to prosper. So it is ironic then that Coggan reflects that his own wife, Charlotte, who was strictly opposed to the use of the swear-word "damn" may herself be currently damned in Hell, simply because she "never was much in luck's way" and resisted the "regular" impulse to swear. This fatalistic view towards repressing the inborn instinct also surfaces in The Mayor of Casterbridge when Michael Henchard takes an oath to quit drinking altogether; yet it is this very decision to shun alcohol that sets him firmly apart from the community argues Joanna Devereux (89). So while Coggan and the maltster officially proclaim to be Christians, their loyalties seem to lie more with nature, a nature for whom certain words - acting as fetishes - must be regularly spoken for harmony to remain. For Charlotte, 
who denies this "natural" impulse to swear, though she is a Christian and Coggan's own wife, Hell may be a necessary evil.

11 This concept of swearing by this problematic word also figures in the fate of Cain Ball. When Cain returns from a trip to Bath, the farm workers, led by Gabriel, press Cain for information, but Cain keeps intermittently coughing. Frustrated, Oak exclaims, "damn the boy" and goes on to threaten him using the full, ominous version of his name "Cain" instead of the softened "Cainy" that is normally used:

"Now Cain Ball", said Gabriel said restlessly, "Can you swear in the most awful form that the woman you saw was Miss Everdene?"

"Cain Ball, you be no longer a babe and suckling" said Joseph in the sepulchral tone the circumstance demanded, "and you know what taking an oath is. "Tis a horrible treatment mind ye, which you say and seal with your blood-stone, and the prophet Matthew tells us that on whomsoever it shall fall it will grind him to a powder. Now before all the work folk here assembled, can you swear to your word as the shepherd here asks ye?"

"Please no, Mister Oak!" said Cainy, looking from one to the other with great uneasiness at the original spiritual magnitude of the position. "I don't mind saying 'tis true, but I don't like to say 'tis damn true, if that's what you mane."

"Cain, Cain, how can you?" asked Joseph sternly. "You be asked to swear in a holy manner, and you swear like wicked Shemei the son of Gera, who cursed as he came. Young man, fie!"

“No, I don't! 'Tis you want to squander a pore boy's soul, Joseph Poorgrass - that's what 'tis!" said Cain, beginning to cry. [...]

"Cain Ball, you'll come to a bit of bread!" groaned Joseph Poorgrass. (Hardy 2002, 221)

12 Though this is often considered a humorous episode, it is significant that the scene and chapter end with the young Cain feeling as if his elders and mentors are "squandering his soul", a charge which they neither deny nor apologize for. Furthermore, Joseph Poorgrass, the most spiritually minded of the "rustics" prophesies ruin for the already illfated Cainy: that he will "come to a bit of bread" because he will not swear on his soul in a "holy" manner, even though Gabriel has just sworn against Cain in an unholy manner. Following this scene, Cain Ball's familiar relationship with the others is never reinstated in the novel. After this, he is only mentioned twice in the text in passing, and he is never again given dialogue or meaningful action.

13 The word as fetish applies to salvation as well as damnation. In a later malthouse scene the characters Jan Coggan, Mark Clark, and Joseph Poorgrass offer their defense of the Anglican tradition over that of the Nonconformists:

"But I've never changed a single doctrine: I've stuck like plaster to the old faith I was born in. [...] Not but that chapel-members be clever chaps enough in their way. They can lift up beautiful prayers out of their own heads, all about their families and shipwrecks in the newspaper."

[...] "But we churchmen, you see, must have it all printed out aforehand, or dang it all, we should no more know what to say to a great person like Providence than to the man in the moon."

"We know very well that if anybody goes to heaven, they will. [...] I'm not such a fool as to pretend we who stick to the church have the same chance as they, because we know we have not. But I hate a feller who'll change his old ancient doctrine for the sake of getting to heaven. [...] No, I'll stick to my side, and if we be wrong, so be it: I'll fall with the fallen."

"The same here," said Mark. "If anything can beat the old martyrs who used to smoke for their principles here on earth 'tis being willing to smoke for "em hereafter." (Hardy 2000, 249) 
Thus Anglican liturgy is the only option these characters have of communicating with God, even though it is not deemed very hopeful compared to the Nonconformists who pray with their "own words." While these characters believe their chance of salvation is substantially lessened by using borrowed, inherited words, they cannot conceive of anything else. Rather than learn new words, they would rather risk damnation or "smoking hereafter"; thus, through the fetishized word of liturgy, they feel a stronger loyalty to their Anglican predecessors than they do with the Christian God. The dialogue above evokes Jude the Obscure's famous epigraph, "The letter killeth" (II Corinthians 3:6). It is as if the speakers agree that: "The letter may kill, and the spirit may give life, but I'll take the letter." While telling, this assertion about "smoking martyrs" never made it into the Cornhill version, as Morgan discusses in Cancelled Words. But Hardy's sincere and personal empathy with these characters is revealed in his autobiography: when confronted with Nonconformist teachings as a young man, he writes of his eventual choice to "stick to his own side" in language that echoes that of the malthouse discussion (Schweik 55).

15 The one character who does try both religious approaches, that is, both "Church and Chapel" is Cain Ball, and he is the character who shuns the idea of taking an oath that risks damnation. Perhaps there is a connection with Cain's determined unaffiliation towards a particular version of Christianity that sets him apart from his neighbors. While Joseph Poorgrass is earlier accused of trying to "squander" Cain's soul (a charge which he did not deny), in this "smoking martyrs" malthouse scene, Joseph is reluctant to share a drink, as he does not want to "squander" his own soul before reaching the "next world" (Hardy 2002, 278). So does Poorgrass believe that it is permissible to squander someone else's soul but not one's own? At any rate he does drink, instead of driving the corpses of "Fanny Robin and child" to the churchyard. Poorgrass defends his right to drink with the invocation "Please God," his favourite word-fetish that he claims always to recite "afore do[ing] anything" - the utterance of which constitutes a "holy act" (Hardy 2002, 281). Whether or not God is actually pleased is immaterial, as the mere word-fetish apparently undoes any wrongdoing in Poorgrass's mind, working as a countercharm similar to the phrases used at the locked gate. "Please God" thus removes any sin-stigma from the state of being drunk, he reasons, as does Michael Henchard in The Mayor of Casterbridge, who, in anticipation of fulfilling his non-drinking pledge, announces "it will be twenty-one years since I swore it, and then I mean to enjoy myself, please God!" (Hardy 2001, 174). Certainly Henchard's resulting disastrous behaviour illustrates the futility of this rationale.

When faced with the ever-changing uncertainties of new religious teachings, Hardy's characters in Far from the Madding Crowd seek consistency and assurance through the literal power of the biblical word. While seemingly used to comic effect in this novel, this sense of religious uncertainty underpinning the word-fetish becomes increasingly restraining in Hardy's last novel Jude the Obscure (1895). Jude Fawley will search for meaning in a world deprived of logos, as Thierry Goater describes it; perhaps Jude's Wessex is simply a matured version of this microcosmic Weatherbury, where biblical words are everywhere, but the characters never truly feel that they know how to speak the right language. 


\section{BIBLIOGRAPHY}

Devereux, Joanna, “'Fools, Rogues, Lammigers, and Wanton Hussies': The Politics of Temperance in Hardy's Fiction”, Human Shows: Essays in Honour of Michael Millgate, eds. Rosemarie Morgan and Richard Nemesvari, New Haven: Thomas Hardy Association, (2000): 89-110.

Doel, Fran and Geoff Doel, Folklore of Dorset, Stroud, Gloucestershire: Tempus, 2007.

Garrigan-Mattar, Sinead, "The Return of the Native: Animism, Fetishism, and the Enchanted Heath", Thomas Hardy Journal 24 (2008): 4-22.

Goater, Thierry, “'The Letter Killeth': the Text as Fetish in Jude the Obscure”, Hardy Review 10.2 (2008): 129-137.

Hardy, Thomas, Far from the Madding Crowd, ed. Rosemarie Morgan, London: Penguin, 2000.

Hardy, Thomas, Far from the Madding Crowd, ed. Suzanne Falck-Yi, Oxford: OUP, 2002.

Hardy, Thomas, The Literary Notebooks of Thomas Hardy, 2 Vols, ed., Lennart A. Bjork, New York: NYU P, 1985.

Hardy, Thomas, The Mayor of Casterbridge, ed. Phillip Mallett, New York: Norton, 2001.

Logan, Peter, Victorian Fetishism: Intellectuals and Primitives, Albany: SUNY, 2009.

Morgan, Rosemarie, Cancelled Words: Rediscovering Thomas Hardy, New York: Routledge, 1992.

Rimmer, Mary, “'My Scripture Manner': Reading Hardy's Biblical and Liturgical Allusion,” Thomas Hardy Reappraised: Essays in Honour of Michael Millgate, ed. Keith Wilson, Toronto: U Toronto P, 2006, 20-37.

Robson, Peter, "Thomas Hardy and His Writings As a Source For the Study of Traditional Culture in Dorset”, Unpublished PhD Diss, U Sheffield, 2004.

Schweik, Robert, “The Influence of Religion, Science, and Philosophy on Hardy's Writings," Cambridge Companion to Thomas Hardy, ed. Dale Kramer, Cambridge: Cambridge UP, 1999, 54-72. Stocking, George W. Jr., After Tylor: British Social Anthropology: 1888 - 1951, Madison: U of Wisconsin $\mathrm{P}, 1995$.

Tylor, Edward Burnett, Primitive Culture (1871), 2 Vols, Cambridge: CUP, 2010.

\section{NOTES}

1. The underlining is Hardy's. 


\section{ABSTRACTS}

This paper looks at how biblical scripture interwoven with folk belief functions as a form of fetishism in Far From the Madding Crowd (1874). Written in the wake of Edward Tylor's Primitive Culture (1871), which popularized the concept of fetishism for a Victorian audience, the novel's fetishized scriptural words are used in a variety of ways: to "magically" open doors, to threaten or curse - even to determine the spiritual state of these characters' souls. Consistently, it is the uttering of the words themselves, rather than the spiritual or figurative message of the scripture that holds sway in Far From the Madding Crowd. While this novel lacks some of the more overt fetishistic practices such as waxen effigy burning found in Hardy's later novel The Return of the Native (1878), its use of words as fetish is important to consider in the development of Hardy's own concept of fetishism, which will become further realized in his later writings.

Cet article explore la façon dont les écrits bibliques et les croyances populaires se mêlent dans Far from the Madding Crowd (1874) pour constituer une forme de fétichisme. Écrit juste avant la parution de Primitive Culture d'Edward Tylor (1871), qui popularisa le concept de fétichisme pour le public victorien, le roman de Hardy emploie des termes bibliques fétichisés de diverses manières : «mots magiques » qui ouvrent des portes, menaces ou malédictions, ils vont jusqu'à déterminer l'état spirituel des personnages. Plus que le message qu'ils contiennent, c'est le fait même de prononcer ces mots qui importe dans Far from the Madding Crowd. Si le roman ne fait pas apparaitre les pratiques fétichistes explicites qui marquent d'autres œuvres comme The Return of the Native (1878), l'utilisation des mots comme fétiches telle qu'elle y figure occupe une place non négligeable dans la façon dont Hardy élabore sa propre vision du fétichisme.

\section{INDEX}

Mots-clés: roman, folklore, fétichisme, Tylor (Edward), Comte (Auguste), langage, Bible oeuvrecitee Far from the Madding Crowd, Return of the Native (The)

Keywords: novel, folklore, fetishism, Tylor (Edward), Comte (Auguste), language, Bible

\section{AUTHOR}

\section{JACQUELINE DILLION}

University of St Andrews

Doctoral candidate 